Original Research

\title{
Determining Polybrominated Diphenyl Ethers in Surface Waters of Western Pomerania Using Gas Chromatography with Electron Capture Detection
}

\author{
Marlena Byczkiewicz*, Maciej Jabłoński** \\ Institute of Chemistry and Environmental Protection, West Pomeranian University of Technology, \\ Al. Piastow 42, 71-065 Szczecin, Poland
}

Received: 10 October 2014

Accepted: 29 December 2014

\begin{abstract}
We show how to determine polybrominated diphenyl ethers in aqueous samples using liquid-liquid extraction and gas chromatography with electron capture detection (LLE-GC- $\mu$ ECD). This method, due to its simplicity, low limits of determination (7-9 pg/L), high accuracy, relatively low costs, and high recovery coefficients for all of these PBDEs (86-92\%), offers enormous benefits for routine analyses of PBDEs. The developed method was applied to surface water samples collected from different sampling points in western Pomerania.
\end{abstract}

Keywords: polybrominated diphenyl ethers, surface water, gas chromatography, liquid-liquid extraction

\section{Introduction}

Polybrominated diphenyl ethers (PBDEs) are classified as persistent organic pollutants. They are added to plastics, paints, coatings, and textiles, as well as resins and polymeric materials to reduce their flammability without the formation of chemical bonds between the additives and the polymeric materials [1-4]. PBDEs are a major danger in the environment because of their constancy, potential ease of getting into it, and toxicity [1-3]. Studies have confirmed their presence in aquatic and terrestrial elements of the environment, for example air, water, sediments, fish, clams, birds, mammals, and human tissues [1, 5-8].

Water as a universal solvent and important agent of transportation of micropollutants can significantly contribute to

*e-mail: marlena.byczkiewicz@zut.edu.pl

**e-mail: maciej.jablonski@zut.edu.pl the transfer and dissemination of PBDEs in the environment. Particularly toxic are the following PBDEs: BDE-28, BDE-47, BDE-99, BDE-100, BDE-153, and BDE-154. Most of these congeners are part of a commercial preparation to delay the combustion process - pentaBDE [3].

PBDE solubility in water decreases with increases in the number of bromine atoms in the molecule, and the partition coefficient octanol/water expressed as log Kow increases with the number of bromine atoms in the molecules of these compounds [4]. Substances with a minor amount of bromine in the molecule, such as BDE-47 and BDE-99, are $90 \%$ of the total content determined in the aqueous phase. Congeners with higher content of bromine are more strongly bound to the sediment particles, making them less mobile in the environment. Literature data on the occurrence of PBDEs in water is limited due to the fact that these compounds are practically insoluble in water [3, 4]. 
In November 2011, a Regulation of the Minister of the Environment introduced monitoring of polybrominated diphenyl ethers in surface waters. According to requirements of minister for environmental regulation, the analytical method for marking PBDEs in superficial water should: get the exact result at the same time as achieve a very low limit of determination $(60 \mathrm{pg} / \mathrm{l})$ and measurement doubt $(\mathrm{k}=2)$, which is less than $50 \%$. It should also be easy in preparation and not require large financial input. Due to analytical problems, only the Provincial Inspectorate for Environmental Protection in Szczecin (WIOŚ) performed such studies (in 2012). In 2013 results of polybrominated diphenyl ethers in superficial water realized WIOŚ in Szczecin and also WIOŚ in Gdansk.

This paper aims to elaborate on the method of determining PBDEs in surface waters, which will be characterized by high accuracy and precision of the results and adequately low detection limits for individual congeners $(<10 \mathrm{pg} / \mathrm{L})$. This method should be particularly useful for routine analysis and would also allow for the characterization of PBDEs in similar aqueous matrices at relatively low cost, and be an easy way for sample preparation. The elaborated methodology for determining PBDE measurements was used for measuring the concentrations of these compounds in water samples collected at different sampling points in western Pomerania.

\section{Materials and Methods}

Standards and Reagents

Individual unlabelled PBDE standards, namely BDE28, BDE-47, BDE-99, BDE-100, BDE-153, and BDE154, were supplied by Cambridge Isotope Laboratories, Inc. USA. This standard included in its composition the following congeners, each at a concentration of $1 \mathrm{ng} / \mu \mathrm{L}$.
The solvent used for extracting n-hexane SupraSolv was produced by Merck (Darmstadt, Germany). For drying the extracts we applied sulfate (VI) of sodium produced by Avantor (Gliwice, Poland).

\section{Apparatus}

To determine the concentrations of PBDEs we used an Agilent Technologies 6890N gas chromatograph with micro-electron capture detector $(\mu \mathrm{ECD})$. The analytes were separated in a ZB-XLB capillary column $(30 \mathrm{~m} \times 0.32 \mathrm{~mm}$ I.D., $0.25 \mu \mathrm{m}$ film thickness, Phenomenex) using a constant helium flow of $2.6 \mathrm{~mL} / \mathrm{min}$. The $\mathrm{GC}$ oven temperature was programmed from $120^{\circ} \mathrm{C}(1.17 \mathrm{~min})$ to $320^{\circ} \mathrm{C}$ at $5^{\circ} \mathrm{C} / \mathrm{min}$. The injector and detector temperatures were set at $250^{\circ} \mathrm{C}$ and $320^{\circ} \mathrm{C}$, respectively. The injection was performed in the pulsed splitless mode. The nitrogen (makeup gas) flow in the micro-ECD system was fixed at $45 \mathrm{~mL} / \mathrm{min}$.

\section{Experimental}

In the presented method, the sample having of $100 \mathrm{~mL}$ was placed in amber glass bottles and $2.5 \mathrm{~mL}$ of n-hexane was added. Next, the sample was stirred using a magnetic stirrer to facilitate complete mixing of the solvent with the water (about $1000 \mathrm{rpm} / \mathrm{min}$ ) for 30 minutes. The samples were then separated in a separator funnel and the organic phase, which was further dried over anhydrous sodium sulfate, was transferred into conical flasks. The resulting extract was concentrated to $100 \mu \mathrm{L}$. Then the concentrated sample was analyzed by gas chromatography. During the method development an assessment of the influence of extractant volume and mixing time on analyte recovery was performed. For this purpose two extractant volumes, namely 2.5 and $5.0 \mathrm{~mL}$, were employed at different mixing times of 15,30 , and 60 minutes.

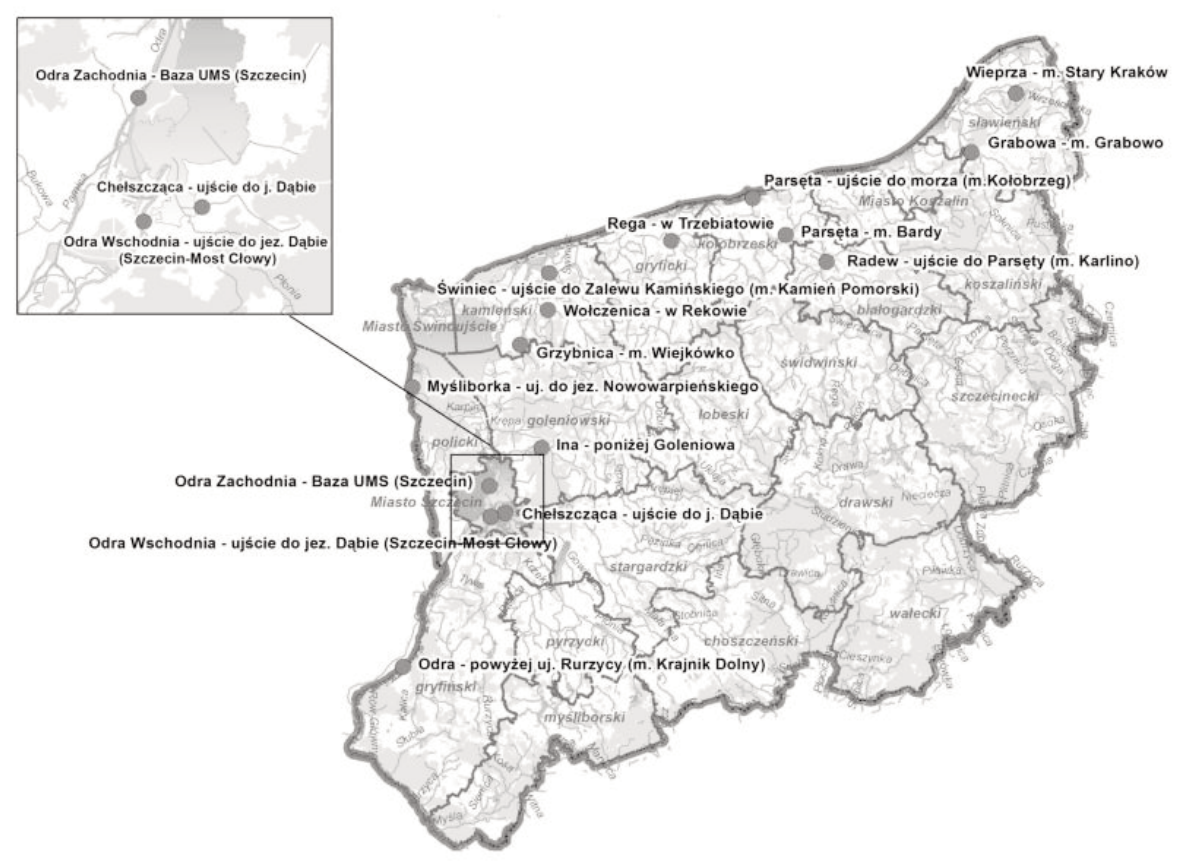

Fig. 1. Control - measurement locations in 2012. 


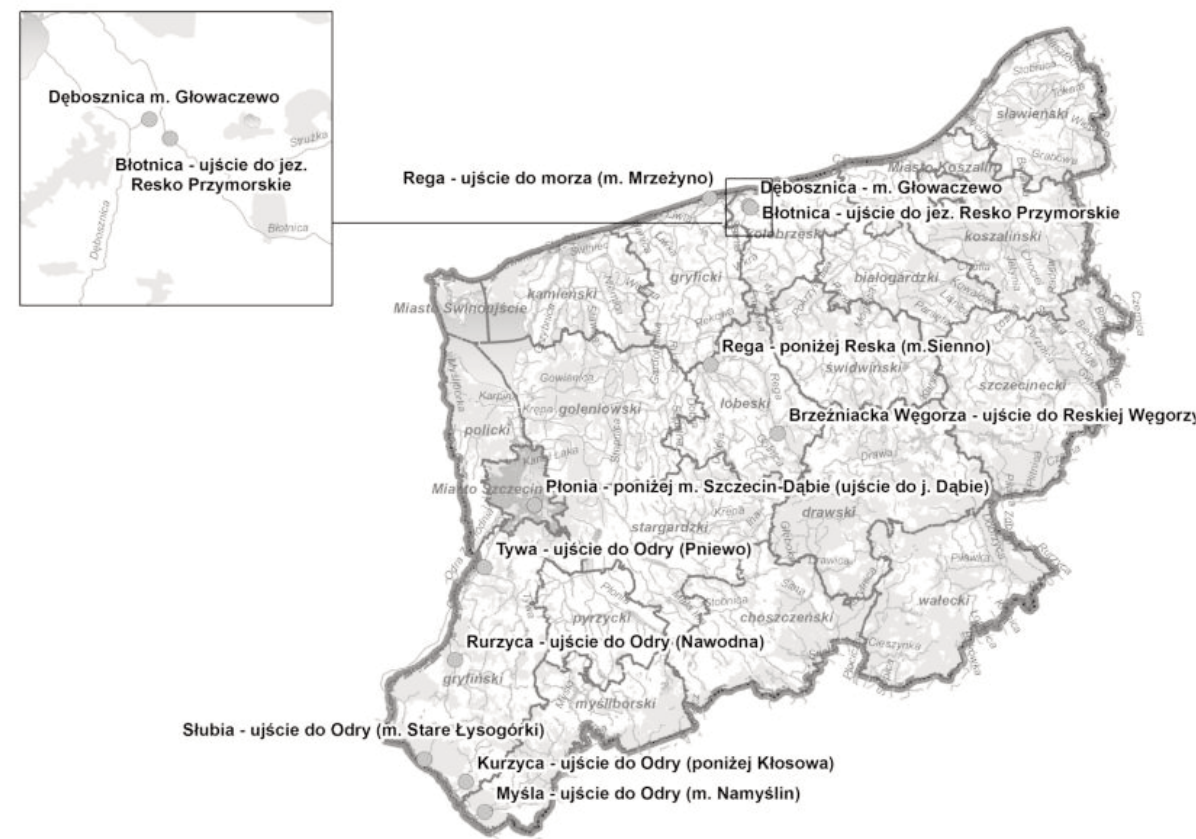

Fig. 2. Control - measurement locations in 2013.

Six calibration solutions ranging from 0.05 to $0.5 \mu \mathrm{g} / \mathrm{L}$ were prepared by serial dilution.

Samples of distilled water were enriched with a known amount of the target analytes in a solvent miscible with water (acetone) and were subjected to extraction, purification, concentration and chromatographic analysis.

To investigate the analytical recoveries of individual PBDE congeners, a pure water matrix was divided into two parts, and then enriched by known volume of PBDE standard solution in a solvent miscible with water (acetone) and was subjected to extraction, purification, concentration, and chromatographic analysis.

Research should approve analysis in water samples of PBDE with a liquid-liquid extraction and gas chromatography with electron capture detection. Experiments were allowed to define the parameters that describe the method used: linear range of calibration, accuracy, precision, limit of detection, limit of quantification, and the degree for separate analyses from aqueous matrix. In western Pomerania samples were taken for testing PBDE in 15 measuring checkpoints, one year after only in 11 (see locations in Figs. 1 and 2). Collection samples of river water were realized 12 times during a year (once a month). Samples were collected into dark glass bottles and stored at $4^{\circ} \mathrm{C}$.

\section{Results and Discussion}

Polybrominated diphenyl ethers are formed by the direct bromination of organic molecules or by the addition of bromine to alkenes [1]. Fig. 3 shows the structure of PBDE molecules and Table 1 presents select information about these compounds.

Table 2 summarizes the validation parameters obtained from the newly developed method. The results were obtained for the samples of surface water. Fig. 4 shows the chromatogram of the PBDE sample. The graph in Fig. 5 shows the influence of the volume of the extraction solvent and the mixing time for recovery. It was found that only volume equal to $2.5 \mathrm{~mL}$ of the extractant and the mixing time $30 \mathrm{~min}$. and the volume of $5.0 \mathrm{~mL}$ and 60 minutes mixing time gave satisfactory recoveries for all congeners. On this basis, subsequent extraction was based on a volume of $2.5 \mathrm{~mL}$ of the extractant and mixing time equal to 30 minutes.

Competence in the determination of PBDEs has been confirmed in proficiency testing AQUACHECK PT Round 457 organized by LGC Standards Proficiency Testing. For individual PBDEs we achieved satisfactory results (z score $<1)$.

The literature contains many studies on the determination of PBDEs using a wide variety of sample preparation techniques. Table 3 shows the number of the most popular and compared with the proposed method based on the extraction of the liquid phase. Under the considerations we took the level of recovery of the analytes from the matrix, the size of the sample, and sample processing time for prop-

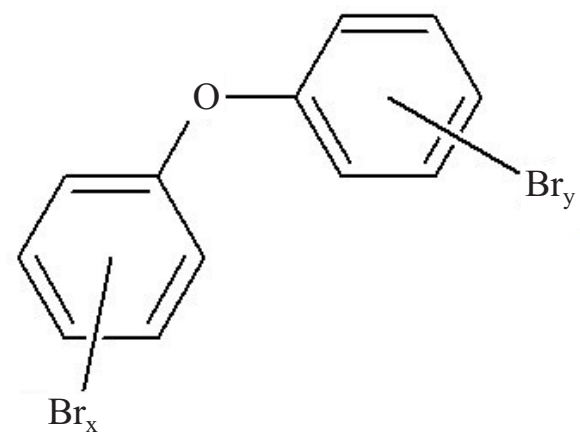

Fig. 3. Chemical structure of PBDEs, where $x+y=1-10$. 
Table 1. Select information about PBDE.

\begin{tabular}{|l|c|c|c|c|}
\hline \multicolumn{1}{|c|}{ Chemical name } & Acronym & CAS No. & Formula & log Kow [9] \\
\hline 2,4,4'-tribromodiphenyl ether & BDE-28 & $41318-75-6$ & $\mathrm{C}_{12} \mathrm{H}_{7} \mathrm{Br}_{3} \mathrm{O}$ & $6.0 \pm 0.6$ \\
\hline 2,4,2',4'-tetrabromodiphenyl ether & BDE-47 & $5436-43-1$ & $\mathrm{C}_{12} \mathrm{H}_{6} \mathrm{Br}_{4} \mathrm{O}$ & $7.4 \pm 0.7$ \\
\hline 2,4,2',4',5- pentabromodiphenyl ether & BDE-99 & $60348-60-9$ & $\mathrm{C}_{12} \mathrm{H}_{5} \mathrm{Br}_{5} \mathrm{O}$ & $8.2 \pm 0.8$ \\
\hline 2,4,2',4',6- pentabromodiphenyl ether & BDE-100 & $189084-64-8$ & $\mathrm{C}_{12} \mathrm{H}_{5} \mathrm{Br}_{5} \mathrm{O}$ & $8.0 \pm 0.8$ \\
\hline 2,4,2',4',5,5'- hexabromodiphenyl ether & BDE-153 & $68631-49-2$ & $\mathrm{C}_{12} \mathrm{H}_{4} \mathrm{Br}_{6} \mathrm{O}$ & $8.9 \pm 0.7$ \\
\hline 2,4,2',4',5,6'-hexabromodiphenyl ether & BDE-154 & $207122-15-4$ & $\mathrm{C}_{12} \mathrm{H}_{4} \mathrm{Br}_{6} \mathrm{O}$ & $9.0 \pm 0.7$ \\
\hline
\end{tabular}

Table 2. Validation parameters of the presented method. Linear range 50-500 ng/L.

\begin{tabular}{|c|c|c|c|c|}
\hline Compounds & RSD (\%) & $\mathrm{r}^{2}$ & LOD (ng.L-1) & $\begin{array}{c}\text { Recovery }(\%) \pm \text { SD } \\
(\mathrm{n}=12) \text { river water }\end{array}$ \\
\hline BDE-28 & 2.35 & 0.99951 & 0.006 & $93 \pm 2$ \\
\hline BDE-47 & 2.23 & 0.99956 & 0.008 & $90 \pm 2$ \\
\hline BDE-99 & 3.87 & 0.99868 & 0.006 & $92 \pm 1$ \\
\hline BDE-100 & 2.14 & 0.99960 & 0.009 & $96 \pm 1$ \\
\hline BDE-153 & 2.06 & 0.99963 & 0.007 & $90 \pm 2$ \\
\hline BDE-154 & 2.90 & 0.99926 & 0.007 & 907 \\
\hline
\end{tabular}

LOD - limit of detection, RSD - relative standard deviation.

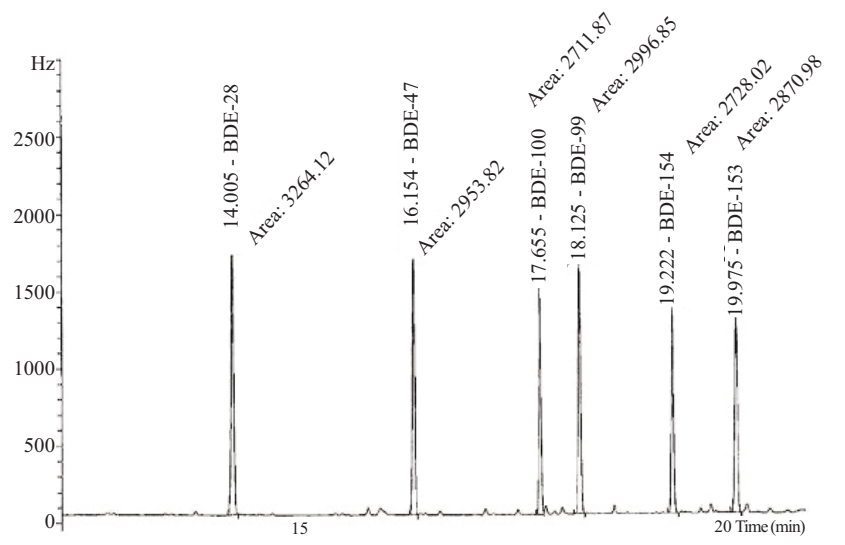

Fig. 4. Typical chromatogram of enriched river water. er analysis. Also important are extraction simplicity, its cost, and hardware requirements.

While analyzing value recoveries for methods of preparation samples we found that recoveries were from $100 \pm 20 \%$. That means results were proper. Only in the case of solid phase extraction [11] did we not achieve rewarding results. The quantity of samples needed to prepare was different for each kinds of method, preparing samples from a few $\mathrm{mL}$ up to $1000 \mathrm{~mL}$ (Table 3).

Taking the estimated time of sample preparation to determine the proper concentration, we can conclude that the present method is less time-consuming in comparison with the headspace sorptive extraction [3]. Reducing the time of analysis, it is possible in the case of frequently

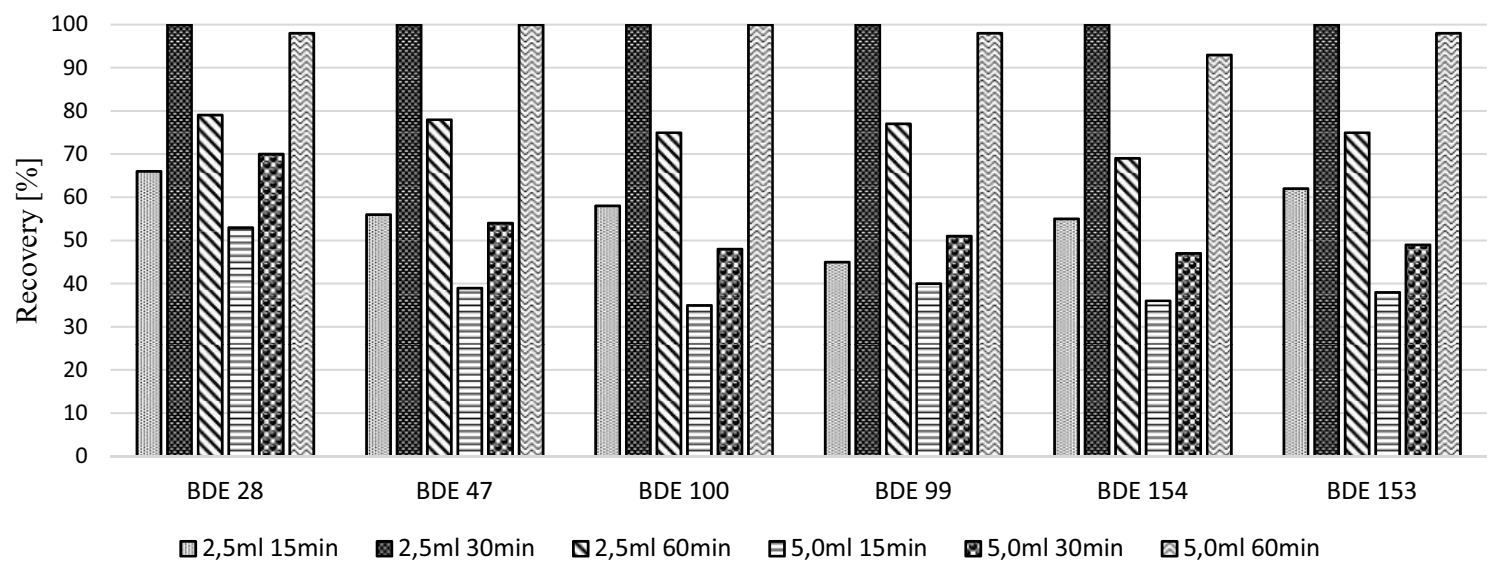

Fig. 5. Influence of extractant volume and mixing time on the recovery of individual PBDE congeners. 
Table 3. Comparison of techniques for sample preparation and extraction methods.

\begin{tabular}{|c|c|c|c|c|c|}
\hline Extraction methods & $\begin{array}{l}\text { Recovery } \\
(\%)\end{array}$ & $\begin{array}{l}\text { Concentration level } \\
\left(\text { ng } \cdot \mathrm{L}^{-1}\right)\end{array}$ & $\begin{array}{l}\text { Sample volume } \\
(\mathrm{mL})\end{array}$ & $\begin{array}{l}\text { Estimated time of } \\
\text { sample preparation }\end{array}$ & References \\
\hline Headspace sorptive extraction & $91-97$ & 100 & 80 & $14 \mathrm{~h}$ & [3] \\
\hline $\begin{array}{l}\text { Hollow-fiber microporous membrane } \\
\text { liquid-liquid extraction }\end{array}$ & $86-103$ & 10 & 100 & $60 \mathrm{~min}$ & [9] \\
\hline $\begin{array}{l}\text { Ultrasound-assisted emulsification- } \\
\text { microextraction }\end{array}$ & $98-103$ & 10 & 10 & $7 \mathrm{~min}$ & {$[10]$} \\
\hline Solid Phase Extraction & $11-47$ & $10-50$ & 1000 & $60 \mathrm{~min}$ & {$[11]$} \\
\hline $\begin{array}{l}\text { Cloud point extraction and ultrasound- } \\
\text { assisted back-extraction }\end{array}$ & $97-108$ & 10 & 10 & $20 \min$ & {$[12]$} \\
\hline $\begin{array}{l}\text { Solid-phase extraction combined with } \\
\text { dispersive liquid-liquid microextraction }\end{array}$ & $72-101$ & 10 & no data & $35 \mathrm{~min}$ & {$[13]$} \\
\hline Liquid-liquid extraction & $80-111$ & 3000 & no data & $1 \mathrm{~h}$ & {$[14]$} \\
\hline $\begin{array}{l}\text { Solid-phase microextraction with } \mathrm{Fe}_{3} \mathrm{O}_{4^{-}} \\
\text {coated bamboo charcoal fiber }\end{array}$ & $79-92$ & 5 & 10 & $6 \mathrm{~h}$ & {$[15]$} \\
\hline $\begin{array}{l}\text { Etched stainless steel wire based on solid- } \\
\text { phase microextraction }\end{array}$ & $77-116$ & 200 & 10 & $50 \mathrm{~min}$ & {$[16]$} \\
\hline $\begin{array}{l}\text { Temperature-assisted ionic liquid dispersive } \\
\text { liquid-liquid microextraction }\end{array}$ & $81-101$ & 10 & 5 & $20 \min$ & {$[17]$} \\
\hline Liquid-liquid extraction & $86-93$ & $1-2$ & 100 & $45 \mathrm{~min}$ & This work \\
\hline
\end{tabular}

Table 4. Comparison of solvents used for PBDE extraction.

\begin{tabular}{|l|c|c|c|}
\hline \multicolumn{1}{|c|}{ Solvent } & $\begin{array}{c}\text { Recovery } \\
(\%)\end{array}$ & $\begin{array}{c}\text { Solvent } \\
\text { volume } \\
(\mathrm{mL})\end{array}$ & References \\
\hline Undecane & $86-103$ & no data & {$[9]$} \\
\hline Trichloromethane & $98-103$ & 0.1 & {$[10]$} \\
\hline Hexane $+20 \mathrm{~g} \mathrm{NaCl}$ & $78-92$ & 100 & {$[11]$} \\
\hline Isooctane & $97-108$ & 0.05 & {$[12]$} \\
\hline Tetrachloroethane & $70-90$ & 0.022 & {$[13]$} \\
\hline Tetrachloromethane & $37-47$ & 0.04 & {$[13]$} \\
\hline $\begin{array}{l}\text { Hexane/MTBE+3\% } \\
\text { DCM in hexan }\end{array}$ & $80-111$ & 100 & {$[14]$} \\
\hline Tetrachloroethane & $116-119$ & 0.02 & {$[18]$} \\
\hline Tetrachloroethylene & $84-104$ & 0.01 & {$[19]$} \\
\hline Hexane & $86-93$ & 2.5 & This work \\
\hline
\end{tabular}

performed measurements by the use of a multi-mixer, which allows parallel preparation of several samples. Moreover, this liquid-liquid extraction is easy to use, and the costs are mainly related to the solvent of suitable purity. The necessary equipment to perform the extraction of this method is associated only with a magnetic stirrer and a rotary evaporator.

In the literature, there are several reports on the use of various solvents for extraction. For the purpose of comparison, solvents used in the present study were selected taking into account their extraction efficiencies in related studies. Other factors that were considered include the cost of the solvent and its toxicity. Selection of various solvents is shown in Table 4.

For extraction of PBDEs we used the following solvents: tetrachloroethene, trichloroethane, carbon tetrachloride, undecane, isooctane, and hexane. For all used solvents results were proper except for tetrachloromethane. In this case, the recovery rate was below $50 \%$. The amount of solvents used for extraction ranged from 0.02-100 mL. Hexane is one of the cheapest solvents compared with others. Mentioned solvents used for extraction are classified as dangerous both for humans and water environments. The most toxic are tri- and tetrachloromethane, which have carcinogenic effects.

The applied measurement method was compared with other methods for the determination of PBDEs. As a criterion for usefulness of the particular measuring methods, we took into account the limit of detection, measurement range, linear correlation coefficient, and the coefficient of variation method. Table 5 presents a summary of these parameters for different methods employed for PBDE determination.

The most frequently described measuring methods for the determination of PBDEs are gas chromatography with mass detector and electron capture detector. The least popular technique is high-performance liquid chromatography. Considering the limit of detection of PBDEs in the presented method, using $\mu$-ECD obtained the lowest limit of detection than that in reported literature. The level of detection for the HPLC method is much higher than other detection methods. A similar conclusion can be obtained for the mea- 
Table 5. Comparison of measurement techniques used to determine PBDE.

\begin{tabular}{|c|c|c|c|c|c|}
\hline $\begin{array}{c}\text { Measurement } \\
\text { techniques }\end{array}$ & LOD $\left(\mathrm{ng} \cdot \mathrm{L}^{-1}\right)$ & Linear range $\left(\mathrm{ng} \cdot \mathrm{L}^{-1}\right)$ & $\mathrm{r}^{2}$ & RSD (\%) & References \\
\hline GC-MS & $1-2$ & $5-10000$ & $>0.998$ & $8.3-10.4$ & {$[10]$} \\
\hline GC-MS & $1-2$ & $4-150$ & $>0.998$ & $4.2-8.3$ & {$[12]$} \\
\hline GC-ECD & $0.06-0.13$ & $0.1-500$ & $>0.999$ & $4.2-7.9$ & {$[13]$} \\
\hline GC-MS & $0.05-0.12$ & $2000-200000$ & $>0.993$ & $6.0-8.0$ & {$[14]$} \\
\hline GC-NCI-MS & $0.25-0.62$ & $1-1000$ & $>0.973$ & $2.4-7.5$ & {$[15]$} \\
\hline HPLC & $12.4-55.6$ & $50-100000$ & $>0.999$ & $3.8-6.3$ & {$[18]$} \\
\hline GC- $\mu$ ECD & $0.006-0.009$ & $0.05-500$ & $>0.998$ & $2.1-3.9$ & This work \\
\hline
\end{tabular}

Table 6. Basic statistical parameters.

\begin{tabular}{|l|c|c|}
\hline & 2012 & 2013 \\
\hline Average value $(\mu \mathrm{g} / \mathrm{L})$ & 0.00024 & 0.0001 \\
\hline Maximum value $(\mu \mathrm{g} / \mathrm{L})$ & 0.00147 & 0.00036 \\
\hline
\end{tabular}

surement range criterion. Comparing the linear correlation coefficients, all described methods obtained very good results. Level and range of concentrations for which these coefficients were determined should be noted.

Results of investigations show that in 2012 in surface water in western Pomerania the most-often stated presence was BDE-47-65\% in general number results over LOQ (LOQ=0.05ng/L) (Fig. 6A). In 2013 the most often stated presence was BDE-28 - 31.1\% in general number results over LOQ (Fig. 6B).

A comparison of 2012 and 2013 shows that BDE-47 is $55.7 \%$, BDE-99 is $14.2 \%, 13.6 \%$ is $100 \mathrm{BDE}, \mathrm{BDE}-28$ is $11.9 \%$, BDE- 153 is $2.3 \%$, and $\mathrm{BDE}$ is $1542.3 \%$ (Fig. 7 ).

Analyzing the average values of PBDE concentration, in 2012 they were two times higher than in 2013 (Table 6). The number of results over LOQ in 2012 were 131, in 2013 only 45. Moreover, in 2012, other than in 2013, monitoring of PBDE contain bigger rivers in western Pomerania, like for example the Odra, Ina, and Parsęta.

Fig. 8 shows proportional share results over LOQ for all measuring checkpoints. The most often presence PBDE was in rivers belonging to the river basin lagoon of Szczecin - the Odra and Myśliborka.

\section{Conclusions}

Gas chromatography with an electron capture detector (GC- $\mu \mathrm{ECD})$ after the extraction of the liquid-liquid is a proper apparatus that lets us determine the PBDEs and meet the earlier mentioned. The method of sample preparation for chromatographic analysis is relatively simple, and results obtained by this method are characterized by high precision and accuracy. The use of a $\mu$-ECD detector allowed us to obtain the limit of determination compatible
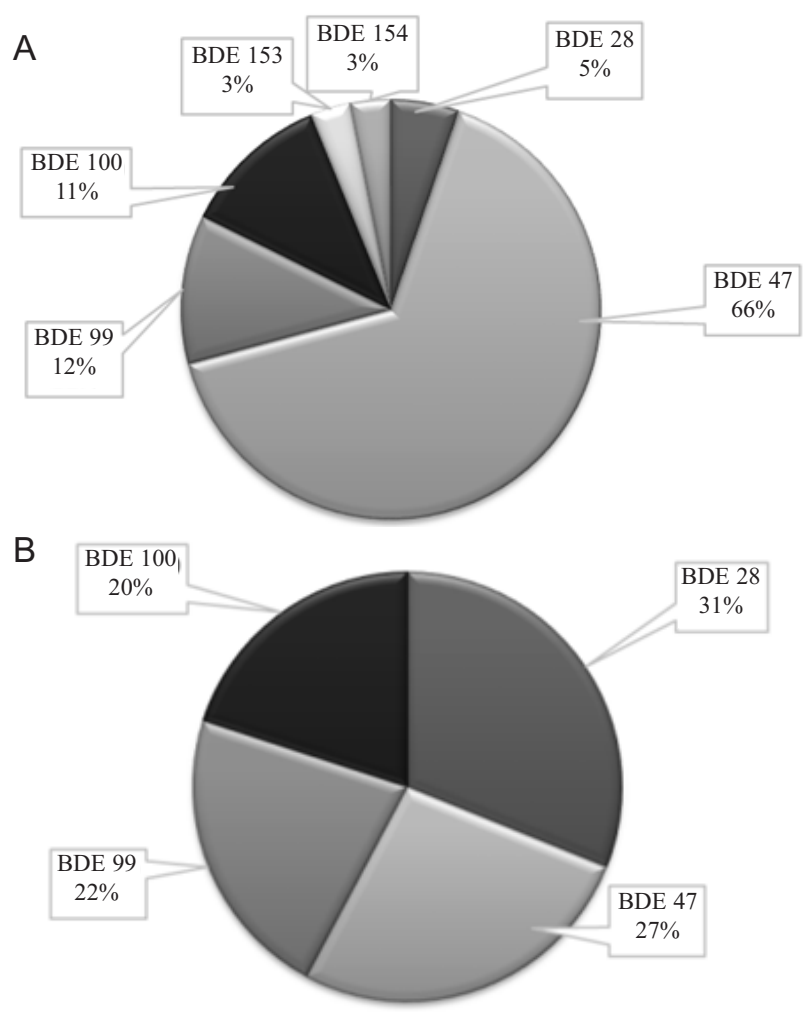

Fig. 6. Participation of individual congeners in the total number of results in 2012 (A) and 2013 (B).

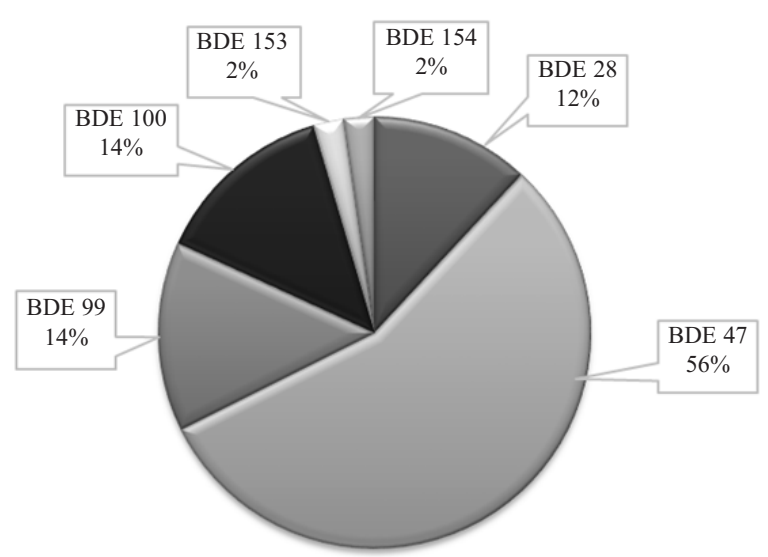

Fig. 7. Participation of individual congeners in the total number of 2012 and 2013 results. 


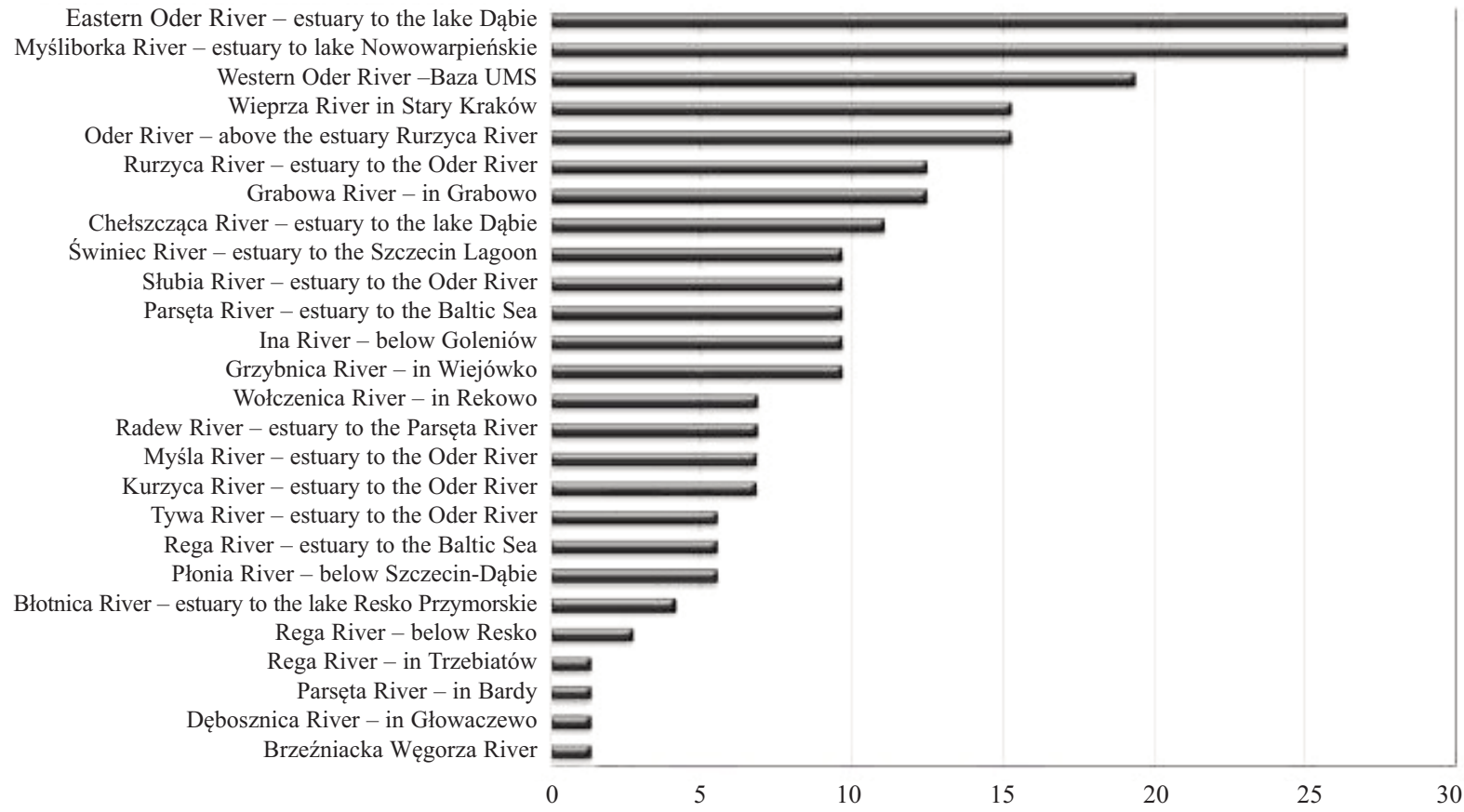

Fig. 8. Percentage participation of results above the LOQ for measuring location points, 2012-13.

with the requirements of Regulation of the Minister of the Environment. Such a low level of concentration determination enables the detection of PBDEs in the environment and verifies that their levels meet rigorous environmental standards. Because of its simplicity, this method's accuracy and low costs are especially useful for routine analysis. This method also meets the requirements for the quantitative determination of PBDEs as stipulated in the Water Framework Directive.

The presence of PBDEs was noticed in all measuring checkpoints covered by State Environment of Monitoring in Western Pomerania in 2012 and 2013. In eight measuring checkpionts we found that $10 \%$ were results obtained for PBDEs relative to general numbers at a measuring checkpoint (results above the LOQ). In researching PBDE, $4.5 \%$ results exceeded maximum permissible value (30\%), as specified in the Regulation of the Minister of the Environment.

\section{References}

1. ĆWIKLAK K., JABŁOŃSKA M. Polybrominated diphenyl ethers in the environment. Laboratorium 9/2008, 10-14, 2008 [In Polish]

2. FULARA I., CZAPLICKA M. Methods for determination of polybrominated diphenyl ethers in environment al samples - review. J. Sep. Sci. 35, 2075, 2012.

3. MONTES R., RODRIGUEZ I., RUBI E., CELA R. Suitability of polydimethylsiloxane rods for the headspace sorptive extraction of polybrominated diphenyl ethers from water samples. J. Chromatogr. A, 1143, 41, 2007.

4. DASO A. P., FATOKI O.S., ODENDAAL J. P. Occurrence of polybrominated diphenyl ethers (PBDEs) and 2,2',4,4',5,5'-hexabromobiphenyl (BB-153) in water sam- ples from the Diep River, Cape Town, South Africa. Environ Sci Pollut Res, 20, 5268, 2013.

5. HERNIK A., GÓRALCZYK K., CZAJA K., STRUCIŃSKI P. I LUDWICKI W. Polybrominated diphenyl ethers (PBDEs) - new danger? Roczn. PZN 58, (2), 403, 2007 [In Polish].

6. GÓRALCZYK K., STRUCIŃSKI P., CZAJA K., HERNIK A. I LUDWICKI J.K. Flame retardants - the use and danger to human. Roczn. PZH 53, (3), 293, 2002 [In Polish]

7. RAHMAN F., LANGFORD K.H., SCRIMSHAW M.D. I LESTER J.N. Polybrominated diphenyl ether PBDE flame retardants. Sci. Total Environ. 275, 1, 2001.

8. de WIT C. An overview of brominated flame retardants in the environment. Chemosphere 46, 583, 2002.

9. FONTANALS N., BARRI T., BERGSTOM S., JONSSON JA. Determination of polybrominated diphenyl ethers at trace levels In enironmental Walters using hollow-fiber microporous membrane liquid-liquid extraction and gas chromatography-mass spectrometry. J. Chromatogr. A 1133, 41, 2006.

10. FONTANA A.R., WUILLOUD R.G., MARTINEZ L.D., ALTAMIRANO J.C. Simple approach based on ultrasoundassisted emulsification-microextraction for determination of polybrominated flame retardants in water samples by gas chromatography-mass spectrometry. J. Chromatogr. A $\mathbf{1 2 1 6}$ 147, 2009.

11. BACALONI A., CALLIPO L., CORRADINI E., GIANSANTI P., GUBBIOTTI R., SAMPERI R., LAGANA A. Liquid chromatography-negative ion atmospheric pressure photoionization tandem mass spectrometry for the determination of brominated flame retardants in environmental water and industrial effluents. J. Chromatogr. A 1216, 6400, 2009.

12. FONTANA A.R., SILVA M.F., MARTINEZ L.D., WUILLOUD R.G., ALTAMIRANO J.C. Determination of polybrominated diphenyl ethers in water and soil samples by cloud point extraction-ultrasound-assisted back-extractiongas chromatography-mass spectrometry. J. Chromatogr. A 1216, 4339, 2009. 
13. LIU X., LI J., ZHAO Z., ZHANG W., LIN K., HUANG C., WANG X. Solid-phase extraction combined with dispersive liquid-liquid microextraction for the determination for polybrominated diphenyl ethers In different enironmental matrices. J. Chromatogr. A 1216, 2220, 2009.

14. SUN J., LIU J., LIU Q., QU G., RUAN T., JIANG G. Sample preparation method for the speciation of polybrominated diphenyl ethers and their methoxylated and hydroxylated analogues in diverse environmental matrices. Talanta 88, 669, 2012.

15. ZHAO R., LIU Y., CHEN X., YUAN J., BAI A., ZHOU J. Preconcentration and determination of polybrominated diphenyl ethers in environmental water samples by solidphase microextraction with $\mathrm{Fe}_{3} \mathrm{O}_{4}$-coated bamboo charcoal fibers prior to gas chromatography-mass spectrometry. Anal. Chim. Acta 769, 65, 2013.

16. CHEN X., CHENG C., WANG X., ZHAO R. Sensitive determination of polybrominated diphenyl ethers in environmental water samples with etched stainless steel wire based on solid-phase microextraction prior to gas chromatography-mass spectrometry. Anal. Methods 4, 2908, 2012.

17. ZHAO A., WANG X., MA M., WANG W., SUN H., YAN Z., XU Z., WANG H. Tempereture-assisted ionic liquid dispersive liquid-liquid microextraction combined with high performance liquid chromatography for the determination of PCBs and PBDEs in water and urine samples. Microchim Acta 177, 229, 2012

18. LI Y., WEI G., HU J., LIU X., ZHAO X., WANG X. Dispersive liquid-liquid microextraction followed by reversed phase-high performance liquid chromatography for the determination of polybrominated diphenyl ethers at trace levels in landfill leachate and environmental water samples. Anal. Chim. Acta 615, 96, 2008.

19. ZHANG Q., LIANG T., GUAN L. Ultrasound-assisted dispersive liquid-liquid microextraction combined with gas chromatography-mass spectrometry in negative chemical ionization mode for the determination of polybrominated diphenyl ethers in water. J. Sep. Sci. 36, 1263, 2013. 